\title{
COMPARISON BETWEEN FOUR USUAL METHODS OF IDENTIFICATION OF Candida SPECIES
}

\author{
Margarida Neves SOUZA(1), Stéfanie Otowicz ORTIZ(1), Marcelo Martins MELLO(1), Flávio de Mattos OLIVEIRA(2),
}

Luiz Carlos SEVERO $(2,3)$ \& Cristine Souza GOEBEL(4)

\begin{abstract}
SUMMARY
Infection by Candida spp. is associated with high mortality rates, especially when treatment is not appropriate and/or not immediate. Therefore, it is necessary to correctly identify the genus and species of Candida. The aim of this study was to compare the identification of 89 samples of Candida spp. by the manual methods germ tube test, auxanogram and chromogenic medium in relation to the ID $32 \mathrm{C}$ automated method. The concordances between the methods in ascending order, measured by the Kappa index were: ID 32C with CHROMagar Candida $(\kappa=0.38)$, ID 32C with auxanogram $(\kappa=0.59)$ and ID $32 \mathrm{C}$ with germ tube $(\kappa=0.9)$. One of the species identified in this study was $C$. tropicalis, which demonstrated a sensitivity of $46.2 \%$, a specificity of $95.2 \%$, PPV of $80 \%$, NPV of $81.1 \%$, and an accuracy of $80.9 \%$ in tests performed with CHROMagar Candida; and a sensitivity of $76.9 \%$, a specificity of $96.8 \%$, PPV of $90.9 \%$, NPV of $91 \%$, and an accuracy of $91 \%$ in the auxanogram tests. Therefore, it is necessary to know the advantages and limitations of methods to choose the best combination between them for a fast and correct identification of Candida species.
\end{abstract}

KEYWORDS: Candida; Auxanogram; ID 32C; Chromogenic medium; Germ tube.

\section{INTRODUCTION}

In recent decades, new diagnostic and therapeutic resources have contributed to alter the natural history of infectious, degenerative and immunosuppressive diseases. Such resources, on one hand, contribute to increase the patients' survival rate, but on the other, can generate "damage" to the host immunity, which becomes a victim of its own colonizing microbiota or organisms until then considered of low pathogenicity ${ }^{26}$. Among the systemic infectious diseases which have been increasing, especially since 1980, we can mention the ones caused by yeast, especially of the genus Candida ${ }^{13}$.

The most common systemic infection caused by that yeast is candidemia, associated with high mortality rates, especially when the antifungal treatment is not immediate or adequate ${ }^{27}$. Candida albicans is considered the main opportunistic pathogenic yeast for being the most frequently isolated species in humans. However, in recent decades, a significant increase in other species such as C. tropicalis, and C. krusei ${ }^{13}$, ${ }^{32}$ has been observed.

The identification of these yeasts at the species level is necessary in order to help in selecting the appropriate antifungal agent for the treatment of serious infections caused by these yeasts ${ }^{10}$. Some of the currently used methods of identification of yeasts from the genus Candida are the germ tube test, manual and automated methods of assimilation of carbohydrates and nitrogen (auxanogram), chromogenic culture media, and molecular techniques ${ }^{31}$.

Among the various molecular techniques, the best known are: multilocus sequence typing (MLST), pulsed-field gel electrophoresis (PFGE), duplex PCR, restriction fragment length polymorphisms (RFLP), random amplified polymorphic DNA (RAPD), length heterogeneity polymerase chain reaction (LH-PCR), and microsatellites ${ }^{4,15}$. The molecular techniques are accurate, sensitive, specific and relatively simple, and have the potential to greatly decrease the time of identification of pathogens that grow slowly or are difficult to grow ${ }^{9,11,22,35}$. Unfortunately, these methods also have their limitations: 1) DNA isolated from fungi need to be of suitable quality ${ }^{14}$; 2) the potential contamination with clinically irrelevant fungal species; 3 ) they require technical skills and expensive equipments ${ }^{7}$ 4) they are not available in all laboratories ${ }^{33}$.

Considering the need to quickly and accurately identify Candida species, not only for their relevance in epidemiological studies, but also to choose the appropriate antifungal treatment so as to reduce the high mortality rate caused by these yeasts, other parameters such as the fact that not all laboratories have automated or semi-automated systems, and molecular biology-dedicated departments, it is worth to use a manual method that is fast, reliable and has high sensitivity and specificity. Therefore, this study aimed to compare the identification of Candida species by ID 32C automated method (bioMérieux, France) with manual 


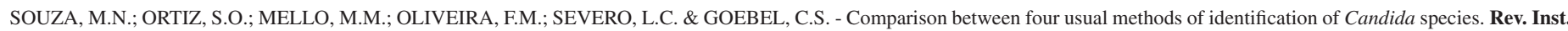
Med. Trop. Sao Paulo, 57(4): 281-7, 2015.

methods of auxanogram, the germ tube test and the chromogenic medium, CHROMagar Candida (Candida CHROMagar, France).

\section{MATERIAL AND METHODS}

Candida samples: Eighty-nine (89) isolates of Candida spp. were obtained from 89 different patients admitted to the Irmandade Santa Casa de Misericórdia de Porto Alegre (ISCMPA) during the period of January to December, 2009. These samples were isolated from different biological specimens, predominantly derived from blood cultures (66 samples), and the remaining samples from urine, ascites, and synovial fluids.

These isolates were previously identified by the ID 32C automated method by the Laboratory of Clinical Mycology of ISCMPA, being this method considered the gold standard in this laboratory. The other tests were performed in the Laboratory of Mycology of the Universidade Federal de Ciências da Saúde de Porto Alegre (UFCSPA).

The ID 32C automated method: The positive cultures were analyzed macroscopically and microscopically and confirmed by the ID 32C automated method - ATB Expression (bioMérieux, France). This method consists of a single-use disposable plastic strip with 32 wells containing substrates for 29 assimilation tests (carbohydrates, organic acids, and amino acids), one susceptibility test (cycloheximide), one colorimetric test (esculin), and a negative control ${ }^{29}$.

The yeast identification procedures were conducted in accordance with the manufacturer's instructions (ID 32C, bioMérieux, France). To perform this, recent colonies $(24 \mathrm{~h})$ were used for the preparation of a standardized suspension of $2 \mathrm{McF}$ arland $(\mathrm{McF}$ ) in a densitometer (ATB 1550, bioMérieux, France). Five drops of this suspension was then dispensed to an ampule of $\mathrm{C}$ medium (Medium $\mathrm{C}$, bioMérieux, France) provided by the manufacturer and homogenized to prepare an even dispersion of inoculum. After homogenizing, the inoculum suspension was used to inoculate the wells in the strip, the lid of the strip was replaced, and the system was incubated at $30{ }^{\circ} \mathrm{C}^{29}$. Then, following the manufacturer's instructions, the reading of the test was performed after $24 \mathrm{~h}, 48 \mathrm{~h}$ and $72 \mathrm{~h}$ of incubation in the equipment ATB Expression.

Germ tube test: The germ tube is a continuous prolongation of the mother cell produced at the beginning of the filamentation process of the yeast $C$. albicans and is considered a transitional form between the yeast and the mycelium ${ }^{13}$. The germ tube walls are parallel and there are no constrictions at the junction with the blastoconide, thus differing from the pseudo-hyphae present in the other species of Candida ${ }^{24}$.

The germ tube test, described by TASCHDJIAN in $1960^{34}$, is a simple screening method for the distinction of $C$. albicans from other yeast species, through observation of germ tube formation. To perform the germ tube test, a suspension was made in a tube containing $0.5 \mathrm{~mL}$ of human serum with a colony of the yeast sample and incubated at 37 ${ }^{\circ} \mathrm{C}$ for up to three hours ${ }^{34}$. After microscopic observation, the samples were considered C. albicans when they formed germ tube and Candida spp. when they did not form germ tubes.

Chromogenic medium - CHROMagar Candida: The chromogenic medium CHROMagar Candida (CHROMagar Candida, France) is available for the isolation and presumptive identification of $C$. albicans, based on the pigmentation of the developing colonies, which is due to different enzyme activities from Candida species. This medium shows different color colonies for C. albicans (green), C. tropicalis (metallic blue, with a pink halo), and C. krusei (pink with velvety appearance) $)^{10}$.

The samples identified as Candida spp. after the germ tube tests performed, were seeded in the CHROMagar Candida. The tests were performed according to the manufacturer's instructions: after $48 \mathrm{~h}$ of incubation at $30^{\circ} \mathrm{C}$, the results were interpreted according to the color of the colony formed.

Auxanogram: carbohydrates assimilation by manual method: The carbohydrate assimilation is the ability of yeast to grow aerobically in the presence of a particular carbohydrate supplied as the only energy source. The test is performed in a nitrogen base medium containing only one carbohydrate. The positivity of the test is measured by observing the growth of yeast in the presence of the carbohydrate supplied ${ }^{31}$.

Eight liquid media of Yeast Nitrogen Base (Himedia, Brazil) were prepared, according to the manufacturer's instructions, each containing one of the following carbohydrates: glucose (positive control), raffinose, galactose, lactose, maltose, trehalose, saccharose or xylose. After 0.5 $\mathrm{mL}$ of each medium were diluted into tubes containing $4.5 \mathrm{~mL}$ of sterile distilled water and $0.5 \mathrm{McF}$ suspension of Candida sample. Following the kit instructions, the tubes were incubated at $25{ }^{\circ} \mathrm{C}$ for seven days and, when there was no growth observed during this period in samples containing xylose and galactose, they were incubated for a further 14 days due to possible delayed growths characteristic of these carbohydrates. The results were classified as negative, weakly negative, weakly positive and positive, according to the turbidity.

Auxanogram: nitrogen assimilation by manual method: The nitrogen assimilation is the ability of yeast to grow aerobically in the presence of particular nitrogen supplied as the only energy source. The test is performed in a carbon base medium containing just one particular nitrogen. The positivity of the test is measured by observing the growth of yeast in the presence of the nitrogen supplied ${ }^{31}$.

Two liquid media of Yeast Carbon Base (Himedia, Brazil) were prepared according to the manufacturer's instructions: mycological peptone nitrogen compound (positive control) and potassium nitrate. Afterwards, $0.5 \mathrm{~mL}$ of each medium was diluted into tubes containing $4.5 \mathrm{~mL}$ of sterile distilled water and $0.5 \mathrm{McF}$ suspension of Candida sample. The tubes were incubated at $25^{\circ} \mathrm{C}$ for six days, following the kit instructions. The results were classified as positive when samples had growth in the medium with potassium nitrate.

From the observations of the results of the auxanogram tests (assimilation of carbohydrates and nitrogen) it was possible to identify the species of the samples.

Statistical analysis: The agreement between methods was analyzed by the Kappa (k) coefficient test, and the diagnostic performance of the manual methods (sensitivity, specificity, predictive values and accuracy) was compared to the ID 32C (gold standard). The ID 32C system was chosen because it has been proven to be accurate, with the advantage of having an extensive database ${ }^{12}$ and being a universally validated method ${ }^{11}$. 
The Kappa agreement test was interpreted as follows: Poor, if $\kappa=0$, Slight, if $\kappa=0$ to 0.20 , Considerable, if $\kappa=0.21$ to 0.40 , Moderate if $\kappa=0.41$ to 0.60 , Substantial, if $\kappa=0.61$ to 0.80 , or Excellent, if $\kappa=0.81$ to 1 . The program used for calculations was the SPSS 16.0.

Ethical guidelines: This study was approved by the Research Ethics Committee of UFCSPA, process number 852/11.

\section{RESULTS}

The frequencies of identification of the 89 samples by the different methods were described in Table 1 . When it was not possible to determine the species of a sample, the result was classified as Candida spp.

In order to measure the agreement between the ID $32 \mathrm{C}$ with the manual methods, the samples were grouped into new groups containing only species that could be identified by both methods (Table 2). The agreement between the germ tube with the ID 32C, considering groups as "albicans" and "non-albicans", was $\kappa=0.9$. In CHROMagar Candida, the samples were grouped as "albicans", "krusei", "tropicalis" and "other species", and the result obtained was $\kappa=0.38$. To calculate the correlation between the ID 32C and auxanogram, the samples were grouped as "albicans", "krusei", "famata”, "tropicalis", "parapsilosis", "glabrata" and "guilliermondii", and the result was $\kappa=0.59$.

The diagnostic performance of the manual methods and the concordance between the methods in relation to the ID $32 \mathrm{C}$ were calculated for the two more frequent species, i.e., $C$. albicans and $C$. tropicalis. However, we could not calculate the performance of the germ tube test for $C$. tropicalis, since the test is not able to identify this species. The results for C. albicans were: germ tube test $-89.3 \%$ sensitivity, 96.7\% specificity, $92.6 \%$ positive predictive value (PPV), 95.2\% negative predictive value (NPV), $94.4 \%$ accuracy and $\kappa=0.9$; CHROMagar Candida - $78.6 \%$ sensitivity, $88.5 \%$ specificity, $75.9 \%$ PPV, 90\% NPV, 85.4\% accuracy and $\kappa=0.7$; Auxanogram $-71.4 \%$ sensitivity, $95.1 \%$ specificity, $87 \%$ PPV, $87.9 \%$ NPV, $87.6 \%$ accuracy and $\kappa=0.6$ (Table 3). The results for $C$. tropicalis were: CHROMagar Candida $-46.2 \%$ sensitivity, $95.2 \%$ specificity, $80 \%$ PPV, $81.1 \%$ NPV, $80.9 \%$ accuracy and $\kappa=0.5$; Auxanogram $-76.9 \%$ sensitivity, $96.8 \%$ specificity, $90.9 \%$ PPV, $91 \%$ NPV, $91 \%$ accuracy and $\kappa=0.8$ (Table 4 ).

\section{DISCUSSION}

Among the 89 strains isolated from patients admitted to the ISCMPA from January to December 2009, the species C. albicans was the most prevalent (31.46\%), followed by C. tropicalis $(29.21 \%)$ and $C$. parapsilosis $(21.35 \%)$, according to the ID 32C method. In the study by ANTUNES et al. ${ }^{1}$, which identified 120 Candida isolates from patients admitted to the ISCMPA from August 2002 to August 2003, a prevalence of $48.3 \%$ of C. albicans, $25.8 \%$ of C. parapsilosis and $13.3 \%$ of $C$. tropicalis were found. Thus, a change was noticed in the frequency of species isolated from patients admitted to this hospital in

Table 1

Comparison of frequencies and percentages found in the results obtained by methods ID 32C, germ tube test, CHROMagar Candida and auxanogram

\begin{tabular}{|c|c|c|c|c|}
\hline Specie & ID 32C & Germ tube test & CHROMagar Candida & Auxanogram \\
\hline C. albicans & $28(31.46 \%)$ & $27(30.34 \%)$ & $29(32.58 \%)$ & $23(25.83 \%)$ \\
\hline C. tropicalis & $26(29.21 \%)$ & 0 & $15(16.85 \%)$ & $22(24.72 \%)$ \\
\hline C. parapsilosis & $19(21.35 \%)$ & 0 & 0 & $13(14.61 \%)$ \\
\hline C. glabrata & $5(5.62 \%)$ & 0 & 0 & $2(2.25 \%)$ \\
\hline C. pulcherria & $3(3.39 \%)$ & 0 & 0 & 0 \\
\hline C.guilliermondii & $2(2.25 \%)$ & 0 & 0 & $1(1.12 \%)$ \\
\hline C. dubliniensis & $1(1.12 \%)$ & 0 & 0 & 0 \\
\hline C. famata & $1(1.12 \%)$ & 0 & 0 & $2(2.25 \%)$ \\
\hline C. krusei & $1(1.12 \%)$ & 0 & $21(23.6 \%)$ & $2(2.25 \%)$ \\
\hline C. lambica & $1(1.12 \%)$ & 0 & 0 & 0 \\
\hline C. lipolytica & $1(1.12 \%)$ & 0 & 0 & 0 \\
\hline C. sake & $1(1.12 \%)$ & 0 & 0 & 0 \\
\hline C. catenulata & 0 & 0 & 0 & $2(2.25 \%)$ \\
\hline C. ciferri & 0 & 0 & 0 & $1(1.12 \%)$ \\
\hline C. pelliculosa & 0 & 0 & 0 & $4(4.50 \%)$ \\
\hline C. rugosa & 0 & 0 & 0 & $4(4.50 \%)$ \\
\hline C. zeylanoides & 0 & 0 & 0 & $1(1.12 \%)$ \\
\hline Candida spp. & 0 & $62(69.66 \%)$ & $24(26.97 \%)$ & $12(13.48 \%)$ \\
\hline Total & $89(100 \%)$ & $89(100 \%)$ & $89(100 \%)$ & $89(100 \%)$ \\
\hline
\end{tabular}


SOUZA, M.N.; ORTIZ, S.O.; MELLO, M.M.; OLIVEIRA, F.M.; SEVERO, L.C. \& GOEBEL, C.S. - Comparison between four usual methods of identification of Candida species. Rev. Inst. Med. Trop. Sao Paulo, 57(4): 281-7, 2015.

Table 2

Agreement between the methods compared to the ID 32C. The samples were grouped into groups containing only species that could be identified by both methods

\begin{tabular}{|c|c|c|c|c|c|c|}
\hline \multirow{2}{*}{ Groups } & \multicolumn{2}{|c|}{ Germ tube } & \multicolumn{2}{|c|}{ CHROMagar } & \multicolumn{2}{|c|}{ Auxanogram } \\
\hline & $\mathbf{N}$ & kappa & $\mathbf{N}$ & kappa & $\mathbf{N}$ & kappa \\
\hline C. albicans & 27 & \multirow{8}{*}{0.9} & 29 & \multirow{8}{*}{0.38} & 23 & \multirow{8}{*}{0.59} \\
\hline C. famata & - & & - & & 2 & \\
\hline C. glabrata & - & & - & & 2 & \\
\hline C. guilliermondi & - & & - & & 1 & \\
\hline C. krusei & - & & 21 & & 2 & \\
\hline C. parapsilosis & - & & - & & 13 & \\
\hline C. tropicalis & - & & 15 & & 22 & \\
\hline Other species & 62 & & 24 & & 24 & \\
\hline Total & 89 & & 89 & & 89 & \\
\hline
\end{tabular}

recent years, reducing the number of $C$. albicans infections and increasing the number of infections caused by Candida non-albicans species such as $C$. tropicalis.

Although the $C$. albicans is the most common etiologic agent in candidiasis, other species have emerged as important opportunistic pathogens, such as $C$. tropicalis $^{28}$. This has been shown in this work, since $68.54 \%$ of the samples were identified as Candida non-albicans, which is consistent with other studies showing that the majority of species isolated in this genus are classified as non-albicans ${ }^{1,21,32}$.

There was similarity between the frequency of $C$. albicans identified by the methods ID 32C (31.46\%), germ tube test $(30.34 \%)$ and CHROMagar Candida (32.58\%), however the auxanogram showed a lower frequency for this species $(25.83 \%)$. There were differences in the identification of other species by CHROMagar Candida. The most prevalent species in this method was $C$. albicans (32.58\%), followed by $C$. krusei and C. tropicalis, accounting for $23.6 \%$ and $16.85 \%$, respectively. In contrast to the high frequency of samples identified as $C$. krusei by CHROMagar Candida, the ID 32C identified this species only in $1.12 \%$ of samples, while in auxanogram the frequency was $2.25 \%$.

Table 3

Diagnostics performances (sensitivity, specificity, predictive value and accuracy) of manual methods and concordance between the methods in relation to the ID 32C, considering only the species C. albicans

\begin{tabular}{|c|c|c|c|c|c|c|c|c|c|}
\hline C. albicans & ID 32C (+) & ID 32C (-) & Total & $\begin{array}{c}\text { Sensibility } \\
(\%)\end{array}$ & $\begin{array}{c}\text { Specificity } \\
(\%)\end{array}$ & $\begin{array}{l}\text { PPV } \\
(\%)\end{array}$ & $\begin{array}{l}\text { NPV } \\
(\%)\end{array}$ & $\begin{array}{c}\text { Accuracy } \\
(\%)\end{array}$ & Kappa \\
\hline Germ tube $(+)$ & 25 & 2 & 27 & & & & & & \\
\hline Germ tube (-) & 3 & 59 & 62 & 89.3 & 96.7 & 92.6 & 95.2 & 94.4 & 0.9 \\
\hline Total & 28 & 61 & 89 & & & & & & \\
\hline CHROMagar (+) & 22 & 7 & 29 & & & & & & \\
\hline CHROMagar (-) & 6 & 54 & 60 & 78.6 & 88.5 & 75.9 & 90.0 & 85.4 & 0.7 \\
\hline Total & 28 & 61 & 89 & & & & & & \\
\hline Auxanogram (+) & 20 & 3 & 23 & & & & & & \\
\hline Auxanogram (-) & 8 & 58 & 66 & 71.4 & 95.1 & 87.0 & 87.9 & 87.6 & 0.6 \\
\hline Total & 28 & 61 & 89 & & & & & & \\
\hline
\end{tabular}

Table 4

Diagnostics performances (sensitivity, specificity, predictive value and accuracy) of manual methods and concordance between the methods in relation to the ID $32 \mathrm{C}$ considering only the species $C$. tropicalis

\begin{tabular}{lccccccccc}
\hline C. tropicalis & ID 32C (+) & ID 32C (-) & Total & $\begin{array}{c}\text { Sensibility } \\
(\boldsymbol{\%})\end{array}$ & $\begin{array}{c}\text { Specificity } \\
(\boldsymbol{\%})\end{array}$ & $\begin{array}{c}\text { PPV } \\
(\boldsymbol{\%})\end{array}$ & $\begin{array}{c}\text { NPV } \\
(\boldsymbol{\%})\end{array}$ & $\begin{array}{c}\text { Accuracy } \\
(\boldsymbol{\%})\end{array}$ & Kappa \\
\hline CHROMagar (+) & 12 & 3 & 15 & & & & & & \\
CHROMagar (-) & 14 & 60 & 74 & 46.2 & 95.2 & 80 & 81.1 & 80.9 & 0.5 \\
\hline Total & 26 & 63 & 89 & & & & & & \\
\hline Auxanogram (+) & 20 & 2 & 22 & & & & & \\
Auxanogram (-) & 6 & 61 & 67 & 76.9 & 96.8 & 90.9 & 91.0 & 91.0 & 0.8 \\
\hline Total & 26 & 63 & 89 & & & & & & \\
\hline
\end{tabular}


The ID 32C method was able to identify the species of all the isolates, while $69.66 \%, 26.97 \%$ and $13.48 \%$ of the samples tested by germ tube test, CHROMagar Candida and auxanogram, respectively, were not able to identify samples at the species level, being classified as Candida spp.

Considering the Kappa index, showed in Table 2, the classifications of the concordance between the methods were: considerable concordance between ID 32C and CHROMagar Candida $(\kappa=0.38)$, moderate concordance between ID 32C and auxanogram $(\kappa=0.59)$ and excellent concordance between ID 32C and germ tube test $(\kappa=0.9)$. Thus, it was observed that CHROMagar Candida is the test that agrees less with the ID $32 \mathrm{C}$, and the best agreement was found between ID $32 \mathrm{C}$ and the germ tube test.

The agreement between the methods considering only the species $C$. albicans with other "non-albicans" (Table 3) was classified as moderate between ID 32C and auxanogram $(\kappa=0.60)$, substantial between ID $32 \mathrm{C}$ and CHROMagar Candida $(\kappa=0.7)$ and excellent between ID 32C and the germ tube test $(\kappa=0.9)$. Therefore, considering the species $C$. albicans, all methods have a satisfactory concordance.

When analyzing the results obtained in Table 3, it can be observed that the CHROMagar Candida showed low sensitivity (78.6\%) and low PPV (75.9\%) for the identification of C. albicans, i.e., only $78.6 \%$ of positive samples for this species were classified as $C$. albicans and the probability of success (correct identification) when the test is positive is $75.9 \%$. The specificity was $88.5 \%$ with a NPV of $90 \%$, indicating that the probability of the test to yield a negative result in the absence of disease is $88.5 \%$, and the probability for the sample to be actually negative for C. albicans when the test result is negative is $90 \%$. The accuracy found was $85.4 \%$, i.e., $85.4 \%$ of the samples were correctly classified. The values found in this study differ from other studies, where sensitivity and specificity rates were found to be more than $90 \%$ for this species s,3,8,10,20. $^{2}$. A recent example was shown in the study of DAEF et al. ${ }^{8}$ in which the sensitivity and specificity of CHROMagar Candida were determined as $96.9 \%$ and $97.9 \%$ for C. albicans.

The auxanogram tests for identification of $C$. albicans showed a slightly higher accuracy than the CHROMagar Candida (87.6\%). The sensitivity for the identification of $C$. albicans was lower compared to CHROMagar Candida (71.4\%), but with a higher PPV (87\%) and high specificity $(95.1 \%)$, with a NPV of $87.9 \%$. The lowest sensitivity of auxanogram for the identification of $C$. albicans is consistent with the lowest frequency found for this species compared to other methods.

Finally, the germ tube test has a very good diagnostic performance with high accuracy values: (94.4\%), sensitivity (89.3\%), specificity (96.7\%), PPV (92.6\%) and NPV (95.2\%). All results found with the germ tube test were more significant than with the other two methods analyzed for the species $C$. albicans.

In relation to the species $C$. tropicalis, as shown in Table 4, we can observe that the diagnostic performance of auxanogram was more sensitive than the CHROMagar's one: $76.9 \%$ and $46.2 \%$, respectively, however the specificities were similar (96.8\% and 95.2\%, respectively); the auxanogram also showed a higher predictive values compared to CHROMagar (PPV = $90.9 \%$ and $80 \%$, respectively; NPV $=91 \%$ and $81.1 \%$, respectively) and also higher accuracy ( $91 \%$ and $80.9 \%$, respectively).
In our study, an important finding in the identification of the species C. krusei was that 14 of 21 samples $(66.67 \%)$ identified as $C$. krusei by CHROMagar Candida were identified as C. parapsilosis by ID 32C and/or the auxanogram tests (data not shown). Such misclassification of species was also found in the study by ESTRADA-BARRAZA et al. ${ }^{11}$. In this study, it was not possible to calculate the diagnostic performance of the species $C$. krusei, since it was found in only one sample, according to the gold standard ID 32C. Thus, further studies should be performed. However, analyzing the study of BALLESTÉ et al. ${ }^{2}$, they found a very low PPV (20\%) for the identification of C. krusei, meaning that only $20 \%$ of the samples classified as positive by the CHROMagar were actually of this species, indicating that the test produces many false-positive results.

Another observation is that the species $C$. parapsilosis is a complex of three species (C. parapsilosis, C. metapsilosis and C. orthopsilosis), however, since the phenotypic differentiation of this complex is only made at the molecular level ${ }^{23}$, we did not make the distinction among the three species of the complex.

Some laboratories have elected the ID $32 \mathrm{C}$ as the gold standard due to its large number of carbohydrate assimilation tests, reducing the use of complementary microscopic tests ${ }^{11}$. However, not all laboratories that provide services of mycological diagnostics have sufficient demand to maintain an expensive equipment like this.

The germ tube test is the gold standard of laboratories for the identification of C. albicans ${ }^{5}$, because besides being a quick and simple technique, among all Candida species, this is the only method able to detect germ tube formation in the presence of human or animal serum when samples are incubated at $37^{\circ} \mathrm{C}$ for two to four hours ${ }^{17,27}$. Moreover, as evidenced in this study, it has a high diagnostic performance for the identification of $C$. albicans. Despite the easy implementation and low cost, the germ tube test does not identify non-albicans species of Candida and cannot be considered absolute, because $5-10 \%$ of $C$. albicans do not form germ tubes ${ }^{18,19}$. In addition, there are reports indicating that other species of non-albicans Candida, such as C. tropicalis and C. parapsilosis can produce very similar structures ${ }^{6}$.

The CHROMagar Candida has the advantages of being a cheap and quick method, able to detect the presence of mixed cultures ${ }^{10}$. However, only C. albicans, C. tropicalis and C. krusei can be observed ${ }^{16,25,26,30}$, although some studies suggest that this medium allows the identification of the species $C$. glabrata and C. dubliniensis ${ }^{16,25}$. Also, in this study, we demonstrated that the CHROMagar was the test that agreed less with the test considered the gold standard, i.e., the ID 32C, besides presenting a low sensitivity for the species $C$. tropicalis and producing many false positive results for $C$. krusei.

In relation to the auxanogram, it has disadvantages such as being laborious, taking at least a week to get the results and being highly susceptible to contamination. However, an advantage observed in this study was its better diagnostic performance for the detection of $C$. tropicalis in relation to the CHROMagar.

Among the techniques analyzed, we conclude that the traditional germ tube test showed the highest sensitivity for the identification of $C$. albicans, however when the result is non-albicans Candida, additional tests are required. The ID $32 \mathrm{C}$ automated method is efficient in identifying 
SOUZA, M.N.; ORTIZ, S.O.; MELLO, M.M.; OLIVEIRA, F.M.; SEVERO, L.C. \& GOEBEL, C.S. - Comparison between four usual methods of identification of Candida species. Rev. Inst. Med. Trop. Sao Paulo, 57(4): 281-7, 2015.

other species of Candida. However, the use of this method is limited by the high cost. The CHROMagar Candida has been previously reported as effective in the laboratory routine, however it showed the least concordance with the ID 32C, the gold standard in this study, besides a low sensitivity for the species $C$. tropicalis. The auxanogram tests have good accuracy, but are more time consuming than other methods.

A rapid and accurate identification of a patient with a Candida spp. infection will impact the mortality rates, the costs of treatment and the hospitalization time ${ }^{10}$. Thus, we conclude that the knowledge of the advantages and limitations of methods is necessary to choose the best combination of methods according to the size of the laboratory and to make a critical evaluation of the results obtained.

\section{RESUMO}

\section{Comparação entre quatro métodos usuais de identificação de espécies de Candida}

A infecção por Candida spp. está associada com alta mortalidade, principalmente quando o tratamento não é adequado, nem imediato. Assim, a correta identificação do gênero e espécie é necessária. O objetivo deste trabalho foi comparar 89 amostras de Candida spp. pelos métodos manuais prova do tubo germinativo, auxanograma e CHROMagar em relação ao método automatizado ID 32C. As concordâncias entre os métodos em ordem crescente, medidas pelo coeficiente de Kappa, foram: ID 32C com CHROMagar Candida $(\kappa=0,38)$, ID 32C com auxanograma $(\kappa=0,59)$ e ID $32 \mathrm{C}$ com tubo germinativo $(\kappa=0,9)$. Uma das espécies identificadas neste trabalho foi a $C$. tropicalis, que demonstrou uma sensibilidade de $46,2 \%$, especificidade de $95,2 \%$, VPP de $80 \%$, VPN de $81,1 \%$ e acurácia de $80,9 \%$ nos testes com CHROMagar Candida e uma sensibilidade de 76,9\%, especificidade de 96,8\%, VPP de 90,9\%, VPN de $91 \%$ e acurácia de $91 \%$ nos testes de auxanograma. Portanto, o conhecimento das vantagens e limitações dos métodos é necessário para a escolha da melhor combinação entre os mesmos visando uma rápida e correta identificação das espécies de Candida.

\section{ACKNOWLEDGMENTS}

We thank the Laboratory of Clinical Mycology ISCMPA for the concession of the samples and results.

\section{REFERENCES}

1. Antunes AG, Pasqualotto AC, Diaz MC, D'azevedo PA, Severo LC. Candidemia in a Brazilian tertiary care hospital: species distribution and antifungal susceptibility patterns. Rev Inst Med Trop Sao Paulo. 2004;46:239-41.

2. Ballesté DR, Arteta Z, Fernández N, Mier C, Mousqués N, Xavier B, et al. Evaluación del medio cromógeno CHROMagar Candida ${ }^{\mathrm{TM}}$ para la identificación de levaduras de interés médico. Rev Med Urug. 2005;21:186-93.

3. Baradkar VP, Mathur M, Kumar S. Hichrom Candida agar for identification of Candida species. Indian J Pathol Microbiol. 2010;53:93-5.

4. Bonfim-Mendonça PS, Fiorini A, Shinobu-Mesquita CS, Baeza LC, Fernandez MA, Svidzinski TIE. Molecular typing of Candida albicans isolates from hospitalized patients. Rev Inst Med Trop Sao Paulo. 2013;55;385-91.

5. Byadarahally Raju S, Rajappa S. Isolation and identification of Candida from the oral cavity. ISRN Dent. 2011;487921
6. Cárdenes CD, Carrillo AJ, Arias A, Rodríguez-Alvarez C, Torres-Lana A, Sierra A, et al. Comparison of Albicans ID2 agar plate with germ tube for presumptive identification of Candida albicans. Diagn Microbiol Infect Dis. 2002;42:181-5.

7. Cortegiani A, Russotto V, Montalto F, Foresta G, Accurso G, Palmeri C, et al. Procalcitonin as a marker of Candida species detection by blood culture and polymerase chain reaction in septic patients. BMC Anesthesiol. 2014;14:1-9.

8. Daef E, Moharram A, Eldin SS, Elsherbiny N, Mohammed M. Evaluation of chromogenic media and seminested PCR in the identification of Candida species. Braz J Microbiol. 2014;45:255-62.

9. Eggimann P, Bille J, Marchetti O. Diagnosis of invasive candidiasis in the ICU. Ann Intensive Care. 2011;1:37.

10. Eraso E, Moragues MD, Villar-Vidal M, Sahand IH, González-Gómez N, Pontón J, et al. Evaluation of the new chromogenic medium Candida ID 2 for isolation and identification of Candida albicans and other medically important Candida species. J Clin Microbiol. 2006;44:3340-5.

11. Estrada-Barraza D, Dávalos Martínez A, Flores-Padilla L, Mendoza-De Elias R, SanchézVargas LO. Comparación entre métodos convencionales, ChromAgar Candida® y el método de la PCR para la identificación de especies de Candida en aislamientos clínicos. Rev Iberoam Micol. 2011;28:36-42.

12. Fricker-Hidalgo H, Vandapel O, Duchesne MA, Mazoyer MA, Monget D, Lardy B, et al. Comparison of the new API Candida system to the ID 32C system for identification of clinically important yeast species. J Clin Microbiol. 1996;34:1846-8.

13. Giolo MP, Svidzinski TI. Fisiopatogenia, epidemiologia e diagnóstico laboratorial da candidemia. J Bras Patol Med Lab. 2010;46:225-34.

14. Gosiewski T, Jurkiewicz-Badacz D, Sroka A, Brzychczy-Włoch M, Bulanda M. A novel, nested, multiplex, real-time PCR for detection of bacteria and fungi in blood. BMC Microbiol. 2014;14:144.

15. Ieda S, Moriyama M, Takashita T, Maehara T, Imabayashi Y, Shinozaki S, et al. Molecular analysis of fungal populations in patients with oral candidiasis using internal transcribed spacer region. PLOS One. 2014;9:e101156.

16. Jabra-Rizk MA, Brenner TM, Romagnoli M, Baqui AA, Merz WG, Falkler WAJ, et al Evaluation of a reformulated CHROMagar Candida. J Clin Microbiol. 2001;39:20156.

17. Jha BK, Dey S, Tamang MD, Joshy ME, Shivananda PG, Brahmadatan K. Characterization of Candida species isolated from cases of lower respiratory tract infection. Kathmandu Univ Med J (KUMJ). 2006;4:290-4.

18. Lacaz CS, Porto E, Martins JE, Heins-Vaccari EM, Melo NT. Tratado de micologia médica Lacaz. São Paulo: Sarvier; 2002.

19. Lipperheide V, Andraka L, Pontón J, Quindós G. Evaluation of the Albicans ID plate method for the rapid identification of Candida albicans. Mycoses. 1993;36:417-20.

20. Madhavan P, Jamal F, Chong PP, Ng KP. Identification of local clinical Candida isolates using CHROMagar Candida as a primary identification method for various Candida species. Trop Biomed. 2011;28:269-74.

21. Maluche ME, Santos JI. Candida sp. e infecções hospitalares: aspectos epidemiológicos e laboratoriais. Rev Bras Anal Clin. 2008;40:65-7.

22. Meletiadis J, Arabatzis M, Bompola M, Tsiveriotis K, Hini S, Petinaki E, et al Comparative evaluation of three commercial identification systems using common and rare bloodstream yeast isolates. J Clin Microbiol. 2011;49:2722-7.

23. Menezes EA, Vasconcelos Júnior AA, Cunha FA, Cunha MC, Braz BH, Capelo LG, et al. Identificação molecular e suscetibilidade antifúngica de Candida parapsilosis isoladas no Ceará, Brasil. J Bras Patol Med Lab. 2012;48:415-20. 

Med. Trop. Sao Paulo, 57(4): 281-7, 2015.

24. Neufeld PM. Manual de micologia médica: técnicas básicas de diagnóstico. Rio de Janeiro: Programa Nacional de Controle de Qualidade; 1999.

25. Pfaller MA, Houston A, Coffman S. Application of CHROMagar Candida for rapid screening of clinical specimens for Candida albicans, Candida tropicalis, Candida krusei, and Candida (Torulopsis) glabrata. J Clin Microbiol. 1996;34:58-61.

26. Pfaller MA, Diekema DJ. Epidemiology of invasive candidiasis: a persistent public health problem. Clin Microbiol Rev. 2007;20:133-63.

27. Posteraro B, De Pascale G, Tumbarello M, Torelli R, Pennisi MA, Bello G, et al. Early diagnosis of candidemia in intensive care unit patients with sepsis: a prospective comparison of $(1 \rightarrow 3)$-b-D-glucan assay, Candida score, and colonization index. Crit Care. 2011;15:R249.

28. Punithavathy PM, Nalina K, Menon T. Antifungal susceptibility testing of Candida tropicalis biofilms against fluconazole using calorimetric indicator resazuri. Ind J Path Microbiol. 2012;55:72-4

29. Ramani R, Gromadzki S, Pincus DH, Salkn IF, Chaturvedi V. Efficacy of API 20C and ID 32C systems for identification of common and rare clinical yeast isolates. J Clin Microbiol. 1998;36:3396-8.
30. San-Millán R, Ribacoba L, Pontón J, Quindós G. Evaluation of a commercial medium for identification of Candida species. Eur J Clin Microbiol Infect Dis. 1996;15:153-8.

31. Sidrim JJ, Rocha MF. Micologia médica à luz de autores contemporâneos. Rio de Janeiro: Guanabara Koogan; 2010.

32. Storti LR, Pasquale G, Scomparim R, Galastri AL, Alterthum F, Gambale W, et al. Candida spp. isolated from inpatients, the environment, and health practitioners in the Pediatric Unit at the Universitary Hospital of the Jundiaí Medical College, State of São Paulo, Brazil. Rev Soc Bras Med Trop. 2012;45:225-31.

33. Szabó Z, Tóth B, Kovács M, Kardos G, Maráz A, Rozgonyi F, et al. Evaluation of the new Micronaut-Candida system compared to the API ID32C method for yeast identification. J Clin Microbiol. 2008;46:1824-5.

34. Taschdjian CL, Burchall JJ, Kozinn PJ. Rapid identification of Candida albicans by filamentation on serum and serum substitutes. AMA Am J Dis Child. 1960;99:212-5.

35. Zaitz C, Campbell I, Marques AS, Ruiz LR, Framil VM. Compêndio de micologia médica. 2. ed. Rio de Janeiro: Guanabara Koogan; 2010.

Received: 13 May 2014

Accepted: 3 November 2014 


\section{Revista do Instituto de Medicina Tropical de São Paulo on line.}

Publications from 1984 to the present data are now available on:

http://www.scielo.br/rimtsp

PAST ISSUES FROM 1959 ON (PDF)

www.imt.usp.br/portal/

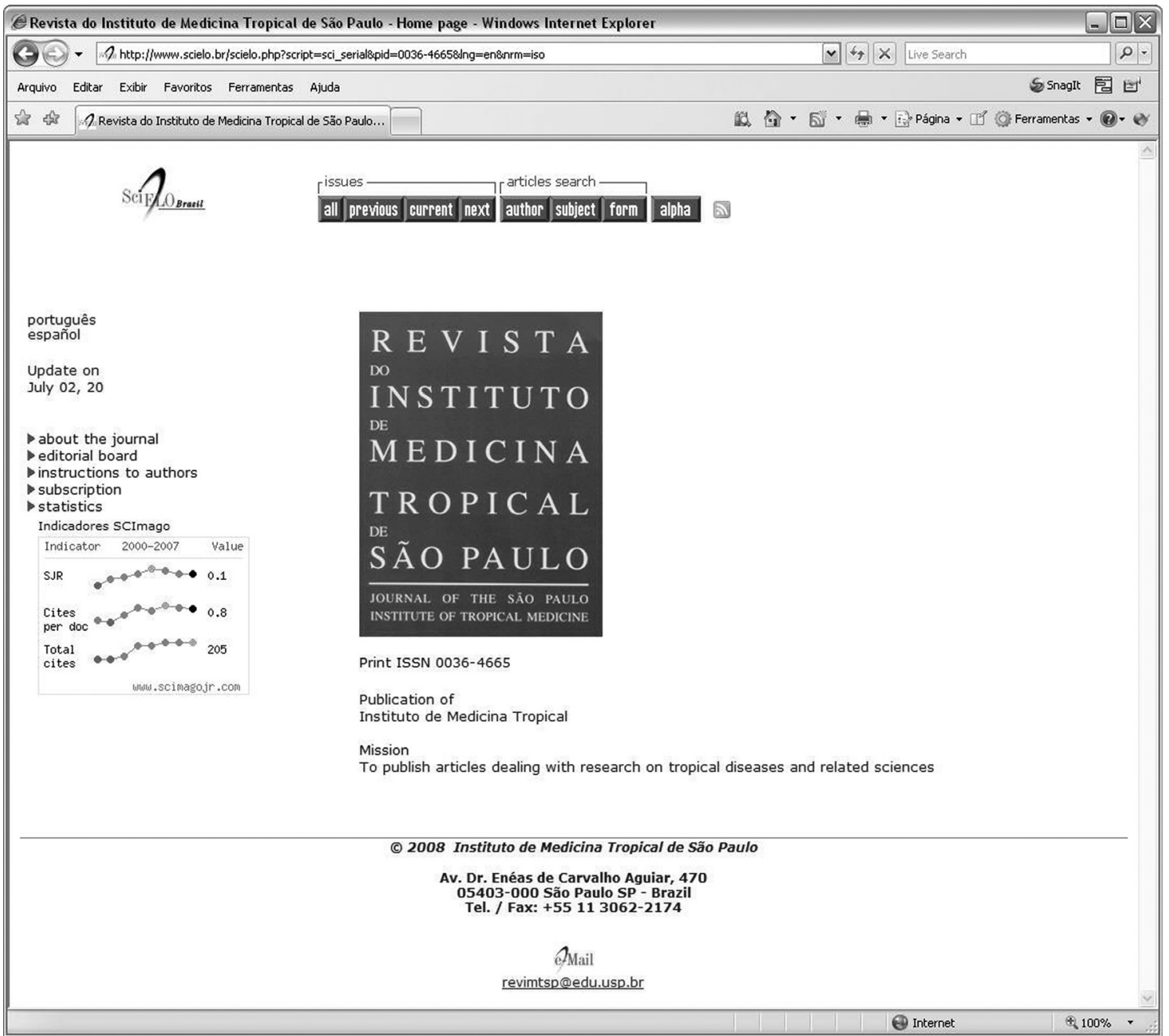

SciELO - The Scientific Electronic Library OnLine - SciELO is an electronic virtual covering a selected collection of Brazilian scientific journals.

The library is an integral part of a project being developed by FAPESP - Fundação de Amparo à Pesquisa do Estado de São Paulo, in partnership with BIREME - the Latin American and Caribbean Center on Health Sciences Information.

SciELO interface provides access to its serials collection via an alphabetic list of titles or a subject index or a search by word of serial titles, publisher names, city of publication and subject.

The interface also provides access to the full text of articles via author index or subject index or a search form on article elements such as author names, words from title, subject and words from full text.

FAPESP/BIREME Project on Scientific Electronic Publications Latin American and Caribbean Center on Health Sciences Information

Rua Botucatu 862 - 04023-901 São Paulo, SP - Brazil

Tel. (011) 5576-9863

scielo@bireme.br 